\title{
RECENT TRENDS IN ACCUMULATION RATE, ELEMENTAL AND ISOTOPIC COMPOSITION OF ORGANIC MATTER IN THE MAGU BAY, LAKE VICTORIA
}

\author{
ANN Muzuka ${ }^{1}$, JF Machiwa $^{2} \&$ C Lugomela ${ }^{3}$ \\ ${ }^{1}$ Institute of Marine Sciences, University of Dar es Salaam, P.O. Box 668, Zanzibar, Tanzania. \\ ${ }^{2}$ Department of Aquatic Environment and Conservation, University of Dar es Salaam, \\ P.O. Box 35064. Dar es Salaam, Tanzania \\ ${ }^{3}$ Department of Fisheries Science and Aquaculture, University of Dar es Salaam, \\ P. O. Box 35064. Dar es Salaam, Tanzania
}

\begin{abstract}
Stable isotope composition of organic carbon $(O C),{ }^{14} \mathrm{C}$ data, $O C$ and nitrogen content of recently deposited sediments in Magu Bay of Speke Gulf, Lake Victoria are used to document accumulation rates, sources and distribution of organic matter in the bay. The stable isotope values of both organic carbon and nitrogen decrease towards offshore, and this trend is associated with increase in the contents of organic carbon and nitrogen. The isotope results show that the organic material deposited in the bay are generally derived from $C_{4}$ type of plants and are not transported far from the river mouth. Also the results show that preservation of organic matter is high in open water probably due to high primary productivity owing to high concentration of nutrients and low in turbidity. Low isotope values in offshore sites indicate that the available stock of nutrients far exceeds the demand. Sedimentation rates in the bay are not high and range from 5 to $54 \mathrm{~cm} / \mathrm{ka}$. This could be attributed to trapping efficiency by shoreline aquatic macrophyte. Furthermore, the mean accumulation rates of organic carbon and nitrogen for the bay, range from 6.92 to $57.25 \mathrm{gC} / \mathrm{m}^{2} / \mathrm{yr}$ and 0.51 to $4.37 \mathrm{gN} / \mathrm{m}^{2} / \mathrm{yr}$, respectively, and show that Magu Bay is currently experiencing eutrophication.
\end{abstract}

\section{INTRODUCTION}

The sedimentary regime of Lake Victoria is complex, the sediment accumulation rates vary from non-deposition to more than a centimeter per millennium in the open lake depositional basins (Hecky et al. 1996). Previous radiocarbon dating of an $18 \mathrm{~m}$ long sediment core from $9 \mathrm{~m}$ depth in Pilking Bay, Lake Victoria, Uganda showed a steady sedimentation rate of approximately 100 $\mathrm{cm} / \mathrm{ka}$ (Kendall 1969). In deeper parts of the lake, sedimentation rate range from $40 \mathrm{~cm}$ to $90 \mathrm{~cm} / \mathrm{ka}$ (Talbot and Lærdal 2000). Although there exist several dated cores from the lake (Talbot and Lærdal 2000), none of these are located in shallower areas closer to mouths of rivers or land in the Tanzanian part of Lake Victoria.

Poor soil management practices in the lake basin and reduction in forests cover have undoubtedly made the area to be prone to erosion (Lipiatou et al. 1996). Sediments records in Lake Victoria provide important paleoclimatic information that prevailed over the region of East Africa. For instance, the total organic carbon (OC) content and $\delta^{13} \mathrm{C}$ signatures of sediment cores retrieved from $32 \mathrm{~m}$ and $66 \mathrm{~m}$ depth in L. Victoria indicated that during the late Pleistocene (between 15.1 and 17.3 thousand years) the lake was dry owing to widespread aridity (Talbot and Livingstone 1989, Johnson et al. 1996, Stager et al. 1997). The Lake Victoria basin sediments, which are organic-rich, also provide historical records of anthropogenic and natural inputs of materials into the lake. Some parameters that can be used include biomarkers, contents of OC and nitrogen, and stable isotopes of $\mathrm{OC}$ and nitrogen. The organic compounds (biomarkers) in sediments that have been rapidly deposited 
under anoxia preserve their identity over long periods of depositional history (e.g. Talbot and Livingstone 1989, Wakeham 1990, Meyers and Ishiwatari 1993).

Most of the reported work in Lake Victoria was conducted in open deeper parts of the lake, and none was conducted in shallow bays. Furthermore, no attempts have been made to evaluate sources of particulate matter in near-shore waters. The stable isotope compositions of $\mathrm{OC}$ and nitrogen are useful parameters in delineating sources of organic matter in the aquatic environment because of distinct nature in terms of isotope composition between various sources of organic material. Materials derived from terrestrial $\mathrm{C}_{4}$ type of plants are characterized by stable isotope values that range from -10 to $-16 \%$ and averaging $-12 \%$ (Deines 1980 , Fry and Sherr 1984, Muzuka 1999a). Furthermore, stable isotope compositions of $\mathrm{C}_{3}$ type of plants range from -24 to $-28 \%$ o averaging -26\% (Deines 1980, Muzuka 1999a). The present work evaluates recent trends in sediment accumulation rate, and type and quantity of organic matter introduced into the lake through the Simiyu river using ${ }^{14} \mathrm{C}$ data, stable isotope composition of $\mathrm{OC}$ and nitrogen and contents of $\mathrm{OC}$ and nitrogen.

\section{MATERIALS AND METHODS \\ Study Area}

Lake Victoria, the greatest among the African Great Lakes and the second largest in the World, has a surface area of about $68,800 \mathrm{~km}^{2}$. The lake is generally shallow, the average and maximum depths being 40 $\mathrm{m}$ and $80 \mathrm{~m}$ respectively. The lake occupies crustal sag between the western and eastern rift shoulders, and was formed as a result of river reversal and pounding during the Cenozoic rifting (Johnson et al. 1996, Stager et al. 1997). Lake Victoria basin overlies Precambrian crystalline and Tertiary volcanic rocks depending on the position in the lake. The sediments are fine grained, of late Pleistocene and Holocene age (Scholz et al. 1990). Quarternary sediments accumulated along the lake, on the east of Speke Gulf, south of Mwanza Gulf, north of Kagera River and east of Nyanza Gulf (Saggerson 1962).

\section{Sampling and analysis}

Fieldwork was conducted in Magu Bay (Fig.1) in May 2001. Sediment samples were recovered from water depths ranging from 0.8 to $15 \mathrm{~m}$ (Table 1) using both box and gravity corers in order to assess levels of $\mathrm{OC}$ and nitrogen as well as the extent of sediment transport offshore. Gravity sediment cores of up to $1 \mathrm{~m}$ were collected for age determination as well as to estimate sediment accumulation rates.

Oven dried $\left(60^{\circ} \mathrm{C}\right)$, crushed, homogenised sediment samples were leached with $1 \mathrm{M}$ $\mathrm{HCl}$ to remove inorganic carbon. The stable isotope compositions of $\mathrm{OC}$ and nitrogen as well as OC and nitrogen content in sediment samples were determined at GEOTOP in Canada using a FINIGAN MAT mass spectrometer. All the isotope data are reported in d-values relative to the PDB (Tyler 1995) and atmospheric nitrogen respectively. Organic carbon and total nitrogen content were determined using a $\mathrm{CHN}$ analyser, and are reported in dry weight percentage. Reproducibility of OC and nitrogen was within $\pm 2 \%$ and $\pm 0.1 \%$ respectively, while those of stable isotopes of $\mathrm{OC}$ and nitrogen were within $\pm 0.1 \%$. No correction of data was made for ${ }^{14} \mathrm{C}$ Accelerated Mass Spectrometer (AMS) dates on total OC. 


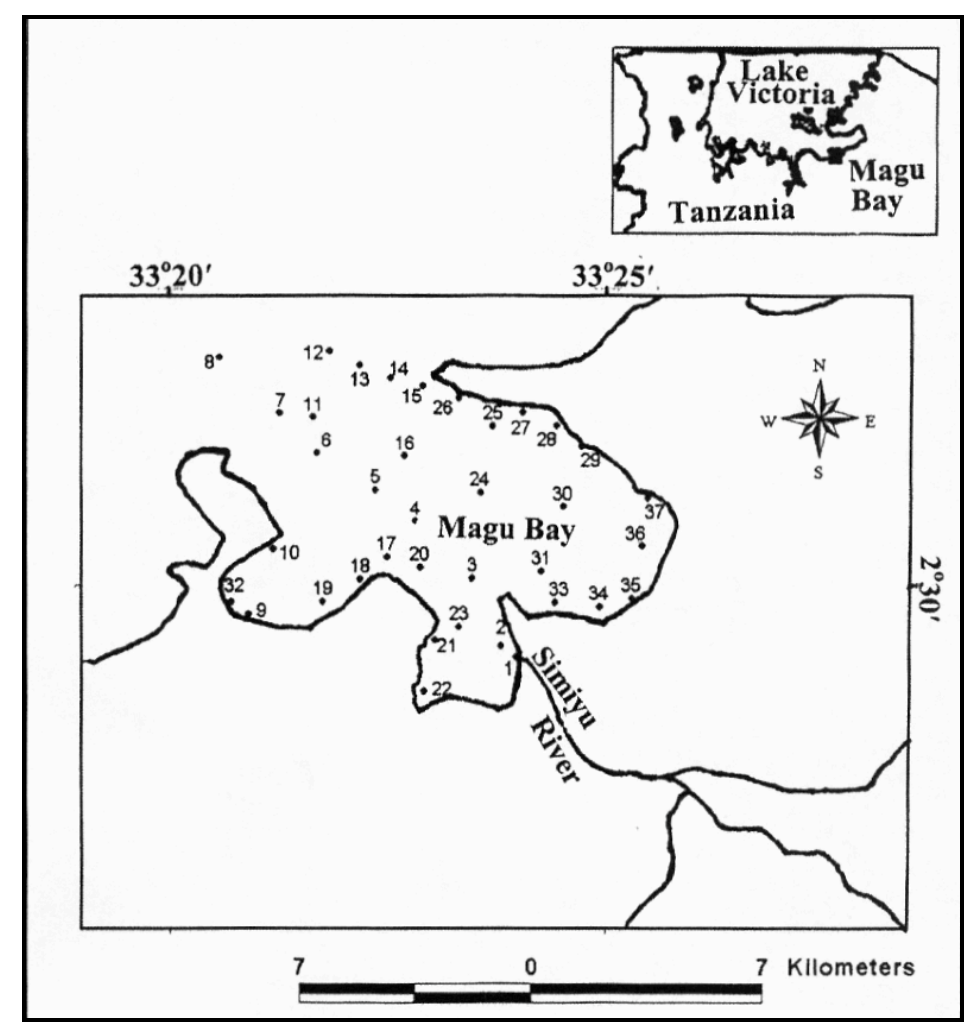

Figure 1: A map showing sampling sites in the Magu Bay of Speke Gulf, Lake Victoria.

Table 1: Locations of sampling stations and water depths

\begin{tabular}{|c|c|c|c|c|c|c|c|}
\hline $\begin{array}{c}\text { Station } \\
\text { No }\end{array}$ & $\begin{array}{c}\text { Latitude } \\
\left({ }^{0} \mathrm{~S}\right)\end{array}$ & $\begin{array}{c}\text { Longitude } \\
\left({ }^{\circ} \mathbf{E}\right)\end{array}$ & $\begin{array}{c}\text { Depth } \\
\text { (m) }\end{array}$ & $\begin{array}{c}\text { Station } \\
\text { No }\end{array}$ & $\begin{array}{c}\text { Latitude } \\
\left({ }^{\circ} \mathrm{S}\right)\end{array}$ & $\begin{array}{c}\text { Longitude } \\
\left({ }^{\circ} \mathrm{E}\right)\end{array}$ & $\begin{array}{c}\text { Depth } \\
\text { (m) }\end{array}$ \\
\hline 1 & $2^{\circ} 31.951^{\prime}$ & $33^{\circ} 25.214^{\prime}$ & 4.1 & 20 & $2^{\circ} 31.243^{\prime}$ & $33^{\circ} 23.719^{\prime}$ & 4.8 \\
\hline 2 & $2^{\circ} 31.660^{\prime}$ & $33^{\circ} 25.056^{\prime}$ & 0.8 & 21 & $2^{\circ} 31.592^{\prime}$ & $33^{\circ} 24.130^{\prime}$ & 1.5 \\
\hline 3 & $2^{\circ} 31.430^{\prime}$ & $33^{\circ} 24.551^{\prime}$ & 3.5 & 22 & $2^{\circ} 32.247^{\prime}$ & $33^{\circ} 24.328^{\prime}$ & 1.5 \\
\hline 4 & $2^{\circ} 30.888^{\prime}$ & $33^{\circ} 23.676^{\prime}$ & 6.1 & 23 & $2^{\circ} 31.150^{\prime}$ & $33^{\circ} 24.484^{\prime}$ & 3.9 \\
\hline 5 & $2^{\circ} 30.360^{\prime}$ & $33^{\circ} 22.655^{\prime}$ & 7.8 & 24 & $2^{\circ} 30.058^{\prime}$ & $33^{\circ} 24.686^{\prime}$ & 5.1 \\
\hline 6 & $2^{\circ} 29.839^{\prime}$ & $33^{\circ} 21.665^{\prime}$ & 9.0 & 25 & $2^{\circ} 28.968^{\prime}$ & $33^{\circ} 24.888^{\prime}$ & 5.4 \\
\hline 7 & $2^{\circ} 28.760^{\prime}$ & $33^{\circ} 21.447^{\prime}$ & 12.0 & 26 & $2^{\circ} 28.326^{\prime}$ & $33^{\circ} 25.027^{\prime}$ & 1.5 \\
\hline 8 & $2^{\circ} 27.682^{\prime}$ & $33^{\circ} 21.290^{\prime}$ & 15.0 & 27 & $2^{\circ} 28.617^{\prime}$ & $33^{\circ} 25.500^{\prime}$ & 3.9 \\
\hline 9 & $2^{\circ} 32.000^{\prime}$ & $33^{\circ} 20.984^{\prime}$ & 1.2 & 28 & $2^{\circ} 28.967^{\prime}$ & $33^{\circ} 25.926^{\prime}$ & 4.2 \\
\hline 10 & $2^{\circ} 30.965^{\prime}$ & $33^{\circ} 21.354^{\prime}$ & 3.9 & 29 & $2^{\circ} 29.247^{\prime}$ & $33^{\circ} 26.388^{\prime}$ & 3.3 \\
\hline 11 & $2^{\circ} 28.829^{\prime}$ & $33^{\circ} 21.985^{\prime}$ & 10.2 & 30 & $2^{\circ} 30.282^{\prime}$ & $33^{\circ} 26.037^{\prime}$ & 3.9 \\
\hline 12 & $2^{\circ} 27.743^{\prime}$ & $33^{\circ} 22.237^{\prime}$ & 12.6 & 31 & $2^{\circ} 31.319^{\prime}$ & $33^{\circ} 25.687^{\prime}$ & 2.7 \\
\hline 13 & $2^{\circ} 27.976^{\prime}$ & $33^{\circ} 22.741^{\prime}$ & 10.5 & 32 & $2^{\circ} 31.894^{\prime}$ & $33^{\circ} 20.645^{\prime}$ & 1.2 \\
\hline 14 & $2^{\circ} 28.177^{\prime}$ & $33^{\circ} 23.233^{\prime}$ & 9.0 & 33 & $2^{\circ} 31.812^{\prime}$ & $33^{\circ} 25.906^{\prime}$ & 1.2 \\
\hline 15 & $2^{\circ} 28.321^{\prime}$ & $33^{\circ} 23.752^{\prime}$ & 7.8 & 34 & $2^{\circ} 31.886^{\prime}$ & $33^{\circ} 26.636^{\prime}$ & 1.7 \\
\hline 16 & $2^{\circ} 29.465^{\prime}$ & $33^{\circ} 23.468^{\prime}$ & 7.2 & 35 & $2^{\circ} 31.788^{\prime}$ & $33^{\circ} 27.248^{\prime}$ & 2.0 \\
\hline 17 & $2^{\circ} 31.090^{\prime}$ & $33^{\circ} 23.190^{\prime}$ & 5.7 & 36 & $2^{\circ} 30.744^{\prime}$ & $33^{\circ} 27.617^{\prime}$ & 2.8 \\
\hline 18 & $2^{\circ} 31.450^{\prime}$ & $33^{\circ} 22.757^{\prime}$ & 2.4 & 37 & $2^{\circ} 29.918^{\prime}$ & $33^{\circ} 27.865^{\prime}$ & 2.6 \\
\hline 19 & $2^{\circ} 31.787^{\prime}$ & $33^{\circ} 22.146^{\prime}$ & 2.1 & & & & \\
\hline
\end{tabular}


Muzuka et al. - Recent trends in accumulation rate ...

RESULTS

Type and content of organic carbon and nitrogen in sediment

Stable isotope values of $\mathrm{OC}$ and nitrogen, contents of $\mathrm{OC}$ and nitrogen, and $\mathrm{C} / \mathrm{N}$ ratios in surface sediment samples that were collected in Magu Bay are summarised in Table 2 .

Table 2: $\quad$ Values of stable carbon and nitrogen isotopes, total organic carbon (OC), total nitrogen and $\mathrm{C} / \mathrm{N}$ ratios of surface sediment samples

\begin{tabular}{|c|c|c|c|c|c|c|c|c|c|c|c|}
\hline $\begin{array}{c}\text { Station } \\
\text { No. }\end{array}$ & $\begin{array}{l}\delta^{13} \mathrm{C} \\
(\%) \\
\end{array}$ & $\begin{array}{l}\delta^{15} N \\
(\%) \\
\end{array}$ & $\begin{array}{c}\mathbf{N} \\
(\%)\end{array}$ & $\begin{array}{r}\text { OC } \\
(\%) \\
\end{array}$ & $\mathrm{C} / \mathbf{N}$ & $\begin{array}{c}\begin{array}{c}\text { Station } \\
\text { No. }\end{array} \\
\end{array}$ & $\begin{array}{r}\delta^{13} C \\
(\% 0)\end{array}$ & $\begin{array}{l}\delta^{15} N \\
(\%)\end{array}$ & $\begin{array}{c}\mathbf{N} \\
(\%)\end{array}$ & $\begin{array}{l}\text { OC } \\
(\%) \\
\end{array}$ & $\mathbf{C} / \mathbf{N}$ \\
\hline 1 & -14.11 & 3.07 & 0.17 & 1.99 & 13.32 & 20 & -17.27 & 2.25 & 0.33 & 3.21 & 11.18 \\
\hline 2 & -16.09 & 0.77 & 0.15 & 1.89 & 14.77 & 21 & -19.09 & 0.72 & 0.05 & 0.26 & 5.58 \\
\hline 3 & -13.92 & 3.59 & 0.18 & 1.74 & 11.59 & 22 & -13.71 & 5.36 & 0.15 & 1.78 & 14.15 \\
\hline 4 & -15.01 & 3.65 & 0.25 & 2.40 & 11.31 & 23 & -14.83 & 3.63 & 3.63 & 2.15 & 13.70 \\
\hline 5 & -15.65 & 3.08 & 0.25 & 2.41 & 11.36 & 24 & -16.10 & -0.95 & 0.23 & 2.48 & 12.67 \\
\hline 6 & -17.94 & 1.71 & 0.43 & 3.31 & 8.90 & 25 & -15.66 & 2.08 & 0.21 & 2.21 & 12.16 \\
\hline 7 & -19.09 & 1.14 & 0.54 & 4.00 & 8.72 & 26 & -19.61 & & 0.07 & 0.32 & 5.34 \\
\hline 8 & -19.49 & 0.37 & 0.54 & 4.60 & 9.98 & 27 & -15.27 & 2.75 & 0.21 & 2.24 & 12.69 \\
\hline 9 & -16.69 & 0.69 & 0.25 & 2.82 & 12.99 & 28 & -14.88 & 1.04 & 0.21 & 2.28 & 12.54 \\
\hline 10 & -18.81 & -0.06 & 0.13 & 0.69 & 6.37 & 29 & -15.70 & 0.05 & 0.24 & 2.54 & 12.24 \\
\hline 11 & -18.55 & 1.99 & 0.47 & 3.63 & 9.05 & 30 & -14.59 & -1.11 & 0.19 & 2.28 & 13.79 \\
\hline 12 & -19.16 & 0.62 & 0.53 & 4.33 & 9.56 & 31 & -14.19 & -1.80 & 0.18 & 2.01 & 13.09 \\
\hline 13 & -18.37 & 2.10 & 0.42 & 3.43 & 9.59 & 32 & -17.21 & -2.00 & 0.33 & 3.16 & 11.13 \\
\hline 14 & -17.65 & 2.04 & 0.33 & 2.51 & 8.96 & 33 & -16.07 & -0.83 & 0.14 & 1.59 & 12.93 \\
\hline 15 & -16.57 & 1.97 & 0.33 & 3.30 & 11.62 & 34 & -15.93 & 0.72 & 0.18 & 2.39 & 15.65 \\
\hline 16 & -15.74 & 2.72 & 0.38 & 1.99 & 6.04 & 35 & -15.64 & 2.47 & 0.18 & 2.53 & 16.37 \\
\hline 17 & -17.31 & 3.45 & 0.43 & 3.07 & 8.36 & 36 & -15.15 & 3.26 & 0.21 & 2.45 & 13.63 \\
\hline 18 & -19.23 & 3.51 & 0.18 & 0.93 & 5.89 & 37 & -15.76 & 2.54 & 0.30 & 3.77 & 14.83 \\
\hline 19 & -18.47 & 5.60 & 0.07 & 0.19 & 3.11 & & & & & & \\
\hline
\end{tabular}

The stable OC isotope compositions for surface sediments, ranged from -19.61 to $13.71 \%$ and averaged $-16.65 \pm 1.75 \%$. Values for $\delta{ }^{13} \mathrm{C}$ decreased with increasing distance from the shoreline (Fig. 2). A similar trend was observed for nitrogen stable isotope values (Fig. 2). There was a positive correlation $\left(\mathrm{r}^{2}=0.53\right)$ between $\delta{ }^{13} \mathrm{C}$ values and $\mathrm{C} / \mathrm{N}$ ratios. However, $\delta{ }^{13} \mathrm{C}$ values negatively correlated with organic carbon and nitrogen contents if six data points corresponding to stations $10,18,19$, 21, 26 and 38) excluded (Fig. 3). Organic carbon content in the surface sediments ranged from 0.19 to $4.60 \%$ and averaged $2.34 \pm 1.10 \%$, whereas total nitrogen content ranged from 0.05 to $0.54 \%$ and averaged $0.25 \pm 0.13 \%$. Generally the organic carbon and total nitrogen contents increased with distance from the shoreline (Fig. 4). Sites located close to the river mouth were characterized by high $\mathrm{C} / \mathrm{N}$ ratios relative to the sites located away from the shore (Fig. 4). The $\mathrm{C} / \mathrm{N}$ ratios ranged from 3.11 to 16.37 and averaged $10.75 \pm 3.37$. 

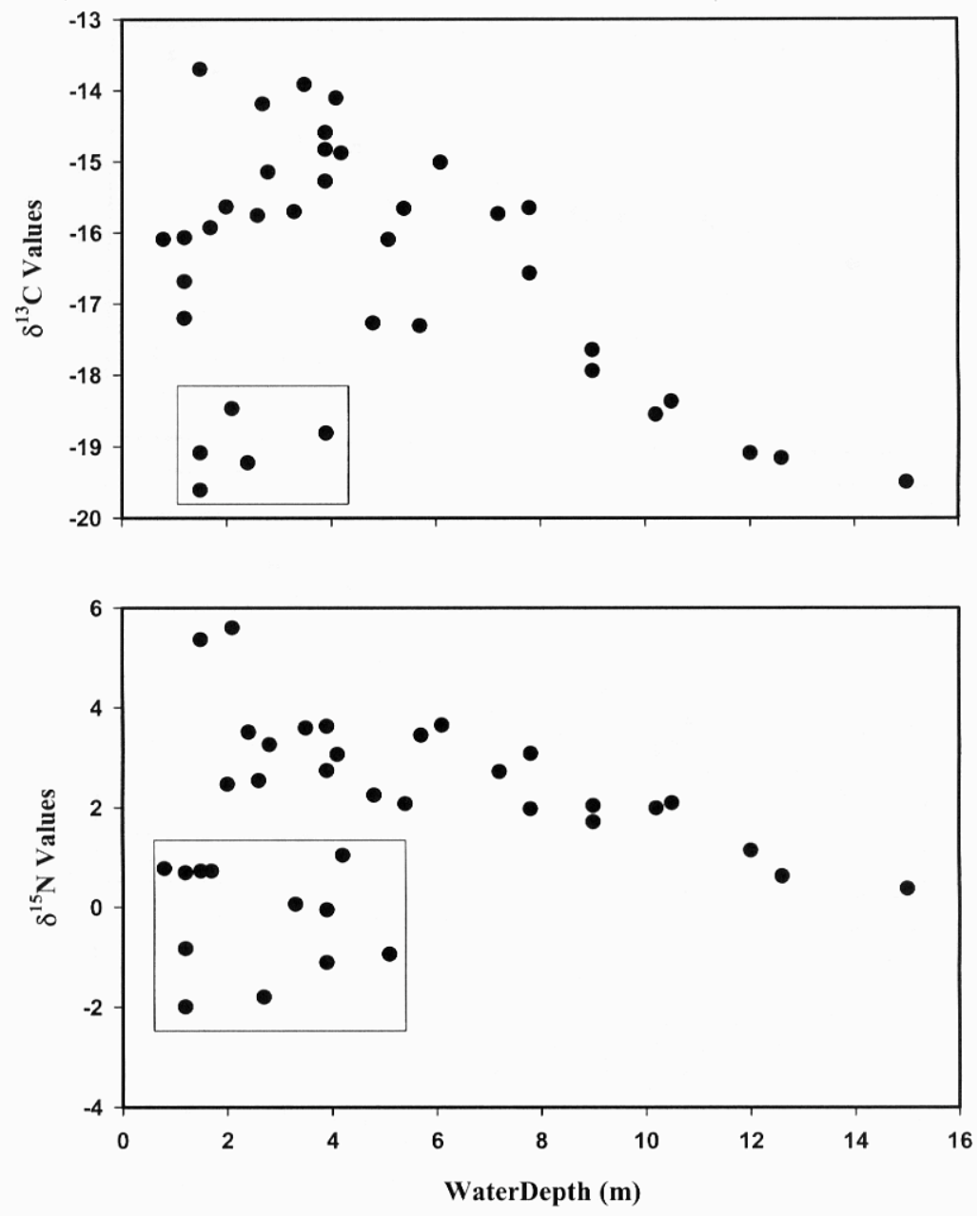

Figure 2: Scatter plots showing variations in the stable isotopes composition of organic carbon and nitrogen with water depth. Correlation improves if data points in boxes are excluded. 

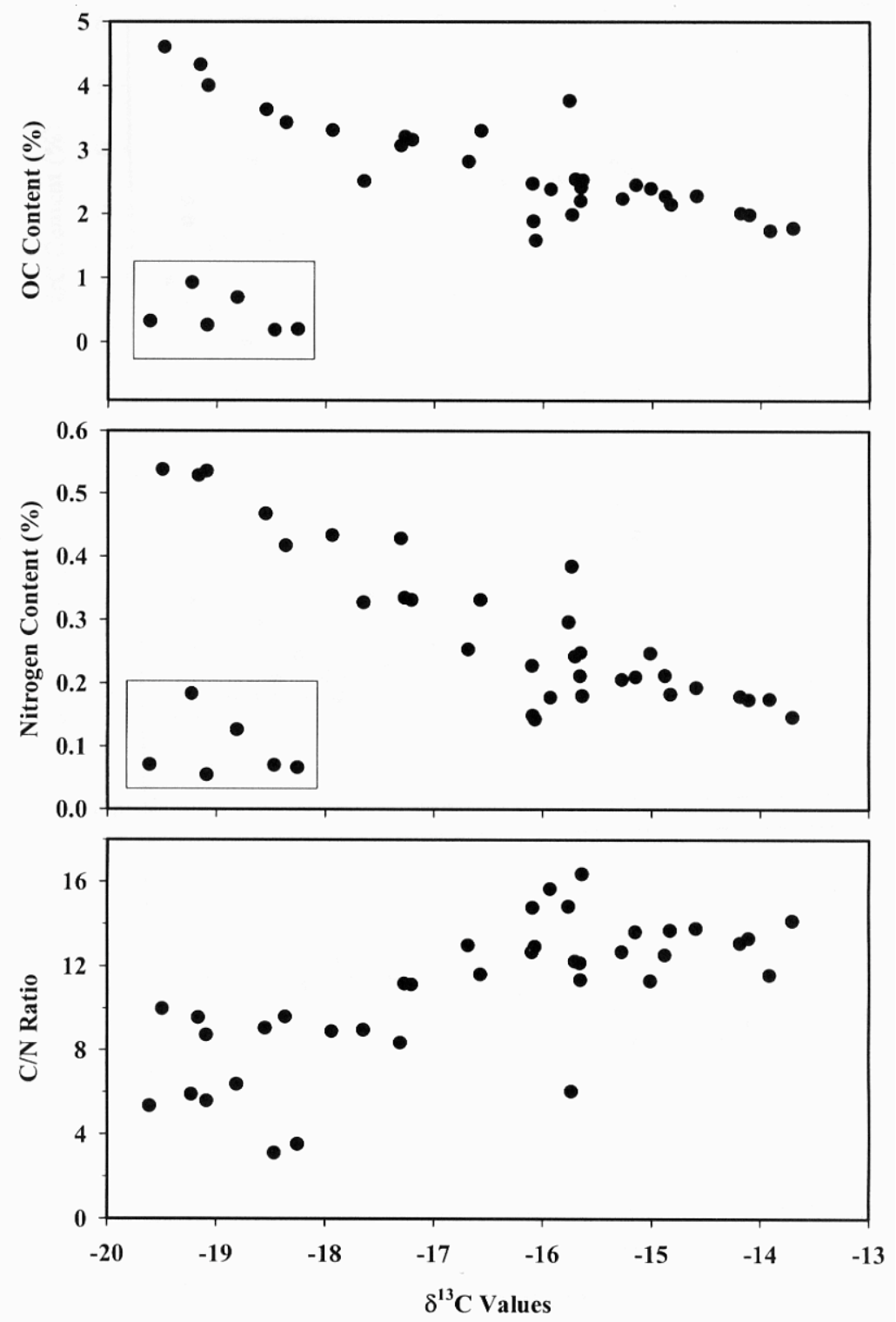

Figure. 3: Scatter plot-showing relationship between $\delta^{13} \mathrm{C}$ values and contents of organic carbon (top), total nitrogen (middle) and $\mathrm{C} / \mathrm{N}$ ratios for surface sediment samples from Magu Bay, Correlation improves if data points in boxes (upper and middle figures) are excluded. 


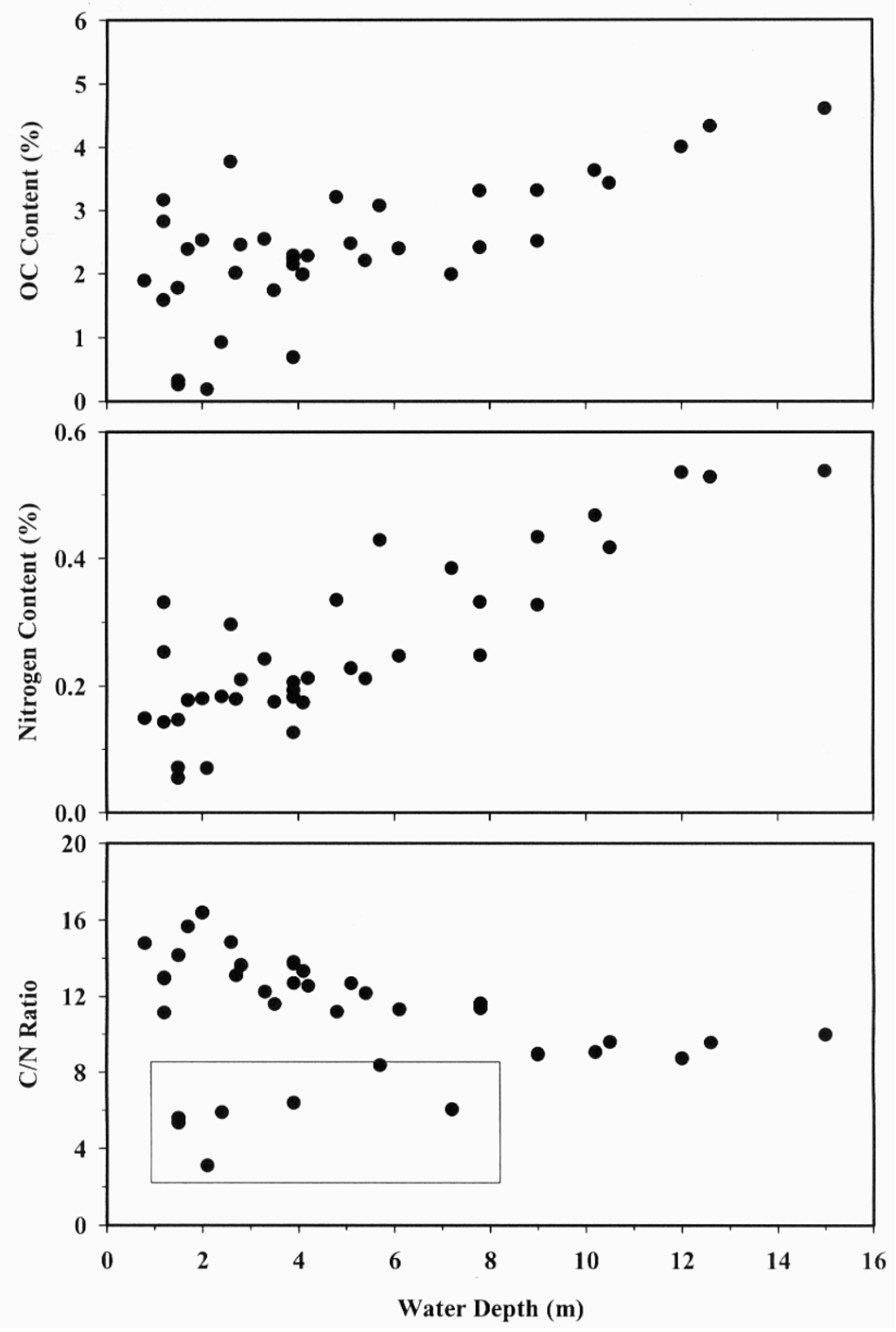

Figure 4: Scatter plots showing variation in the contents of organic carbon (top), total nitrogen (middle) and $\mathrm{C} / \mathrm{N}$ ratios (bottom) with water depth. Because water depth increases with distance from the shoreline, the scatter plots indicate trends of these parameters with increasing distance away from the shore. 


\section{Accumulation Rate of Organic Carbon and Nitrogen}

The mean accumulation rates of organic carbon and nitrogen for the Magu Bay, ranged from 6.92 to $57.25 \mathrm{gC} / \mathrm{m}^{2} / \mathrm{yr}$ and
0.51 to $4.37 \mathrm{gN} / \mathrm{m}^{2} / \mathrm{yr}$, respectively, (Table 3). There was no clear trend for OC and nitrogen accumulation rates with respect to location in the bay.

Table 3: Sedimentation rates $(\mathrm{cm})$, mean values of contents of organic carbon and nitrogen, $\mathrm{C} / \mathrm{N}$ ratios, total accumulation rate (TO-AR in $\mathrm{g} / \mathrm{m}^{2} / \mathrm{yr}$ ), and accumulation rates for organic carbon (OC-AR in $\mathrm{gC} / \mathrm{m}^{2} / \mathrm{yr}$ ) and nitrogen (N-AR in $\mathrm{gN} / \mathrm{m}^{2} / \mathrm{yr}$ ) for various short cores collected from Magu Bay

\begin{tabular}{|c|c|c|c|c|c|c|c|}
\hline $\begin{array}{c}\text { CORE } \\
\text { No }\end{array}$ & $\begin{array}{c}\mathrm{SR} \\
\text { (cm/ka) }\end{array}$ & OC (\%) & N (\%) & $\mathrm{C} / \mathrm{N}$ & $\begin{array}{c}\text { Mass-AR } \\
\left.\mathrm{g} / \mathbf{m}^{2} / \mathbf{y r}\right)\end{array}$ & $\begin{array}{c}\text { OC-AR } \\
\left(\mathrm{gC} / \mathrm{m}^{2} / \mathrm{yr}\right)\end{array}$ & $\begin{array}{c}\mathrm{N}-\mathrm{AR} \\
\left(\mathrm{gN} / \mathrm{m}^{2} / \mathrm{yr}\right)\end{array}$ \\
\hline LV 4 & 8.6 & 2.63 & 0.23 & 13.41 & 33.40 & 8.82 & 0.77 \\
\hline LV 5 & 19.5 & 4.82 & 0.38 & 14.67 & 59.98 & 28.36 & 2.27 \\
\hline LV 8 & 8.6 & 7.02 & 0.69 & 12.07 & - & - & - \\
\hline LV 11 & 8.6 & 5.31 & 0.51 & 11.98 & 22.17 & 12.00 & 1.15 \\
\hline LV 15 & 7.0 & 4.78 & 0.35 & 15.89 & 23.35 & 11.65 & 0.83 \\
\hline LV 22 & 54.3 & 2.27 & 0.18 & 14.40 & 240.66 & 57.25 & 4.37 \\
\hline LV 24 & 8.6 & 3.47 & 0.25 & 15.98 & 20.50 & 6.92 & 0.51 \\
\hline LV 30 & 21.4 & 3.03 & 0.22 & 15.86 & 92.59 & 27.39 & 2.02 \\
\hline LV 31 & 25.2 & 1.96 & 0.14 & 16.10 & 134.49 & 25.53 & 1.90 \\
\hline LV 36 & 21.4 & 3.66 & 0.22 & 18.94 & 62.88 & 21.93 & 1.36 \\
\hline
\end{tabular}

\section{DISCUSSION}

\section{Sources of organic carbon in Magu Bay}

The stable isotope compositions of coastal terrestrial trees $\left(\mathrm{C}_{3}\right.$ plants $)$ and grasses $\left(\mathrm{C}_{4}\right.$ plants) in Tanzania averages $-28 \%$ and 12\% respectively (Muzuka 1999a). Assuming that these are end members for plant materials from the Magu Bay catchment area, a mean isotope value of $16.65 \pm 1.77 \%$ indicate little contribution of land derived $\mathrm{C}_{3}$ vegetation as well as that of lacustrine phytoplanktonic materials. The stable isotope composition of lacustrine phytoplankton has been observed to be similar to or less than that of $\mathrm{C}_{3}$ land plants (LaZerte and Szalados 1982, LaZerte 1983, Aravena et al. 1992, Meyers 1994, de Giorgio and France 1996, Mitchell et al. 1996, Tenzer et al. 1997). The major source of organic material in shallower areas of Magu Bay is mainly $\mathrm{C}_{4}$ type of material from the watershed. Terrestrial organic material is characterized by low nitrogen content while aquatic plants have high nitrogen content. Enriched ${ }^{13} \mathrm{C}$ vales of about $16 \%$ shows that the material is largely derived from $\mathrm{C}_{4}$ type of vegetation such as grasses.

The stable isotope composition of organic carbon in Magu Bay decreased offshore similar to the trend observed off Zanzibar town and in the Dar es Salaam harbour (Muzuka 1999b, 2001). This trend can be attributed to the decrease in the influence of terrestrial material with increasing distance from the shoreline. This observation is further supported by the $\mathrm{C} / \mathrm{N}$ ratio values that decrease with distance from the shore (Fig. 4). The positive correlation between $\mathrm{d}^{13} \mathrm{C}$ values and $\mathrm{C} / \mathrm{N}$ ratios (Fig. 3) also suggest that terrigenous materials are not transported far offshore. The correlation is positive because the terrestrial organic matter is rich in wax material, thus high $\mathrm{C} / \mathrm{N}$ ratios, whereas phytoplanktonic organic matter is rich in nitrogen and thus low $\mathrm{C} / \mathrm{N}$ ratios. Even though the contribution of $\mathrm{C}_{4}$ plants to organic matter in Magu Bay is high, more than $50 \%$ of allochthonous 
materials are deposited close to the river mouth. Lack of a pronounced offshore transport of particulate material could be a result of weak currents or poor circulation causing limited flushing of the area (Machiwa et al. 2003). The presence of shoreline vegetation helps to reduce the velocity of water as well as to trap most of the riverine suspended load. Therefore fringing wetlands with dense growth of shoreline macrophytes need to be preserved in order to check sedimentation rate in the lake.

Because the stable isotope compositions of organic carbon indicate progressive increase in phytoplanktonic material offshore, an increase in organic carbon content offshore may be attributed to a decrease in dilution by siliciclastic material and/or high primary productivity further away from the shore. The high primary productivity offshore probably is a result of large amount of nutrients originating from land as well as a decrease in the concentration of suspended particles leading to increased water transparency. This is in agreement with the secchi disc and suspended particle concentration results, showing light penetration to be limited to a few centimetres in shallow areas of the bay that are associated with high concentration of suspended particles (Machiwa et al. 2003).

The present results show that nitrogen isotope values decrease away from the shore (Fig. 2). Generally in areas with high nutrient concentration far exceeding demand by primary producers the depositing material is generally depleted in ${ }^{15} \mathrm{~N}$ (Nakatsuka et al. 1992, Altabet and Francois 1994, Montoya 1994). Thus, the observed trend suggest nutrient enrichment away from the shore apart from indicating decrease in the relative proportion of land derived material offshore.

In highly polluted lakes the organic carbon and total nitrogen contents are generally greater than $2 \%$ and $0.2 \%$, respectively. Therefore, a mean value of $2 \%$ observed in this study (Table 2 and 3 ) suggests a considerable level of eutrophication. Preservation of organic matter is a function of sedimentation rate, water depth, primary productivity, and particle size (Pedersen et al. 1992, Canfield 1994, Meyer 1994), thus shallower sites are expected to have higher contents of organic matter than the sites located further away from the shore. But of in Magu Bay the relatively low OC in nearshore sediments could be a result of dilution by clastic material. However, higher contents of OC and nitrogen in sediment samples collected from sites far away from the shore suggest large input of nutrients from the catchment.

\section{Recent Accumulation Rates of Organic Carbon and Nitrogen}

The work of Talbot and Lærdal (2000) indicated that Lake Victoria has high sedimentation rates ranging from $40 \mathrm{~cm}$ to $90 \mathrm{~cm} / \mathrm{ka}$. In contrast, the present work shows that sedimentation rate is low ranging from 8 to $25 \mathrm{~cm} / \mathrm{ka}$ with the exception of station 22 (core LV 22) where sedimentation rate averages $54 \mathrm{~cm} / \mathrm{ka}$ (Table 3 ). Because of shallower depth, it is expected that the sedimentation rates in the present study should be relatively higher than the rates reported by Talbot and Lærdal (2000). The low sedimentation rates could be attributed to the trapping efficiency of suspended sediments by the shoreline macrophytes such as Cyperus papyrus or it could also be as a result of preservation of old carbon in the sediment. The stable isotope results of organic carbon show that there is a significant proportion of $\mathrm{C}_{4}$ derived material in Magu Bay deposits, and thus making old carbon to be a major suspect responsible for the obtained old ages. Owing to turbid water close to the shoreline, productivity and thus preservation of OC is low.

It is estimated that freshwater lakes in the World have a total area of about $1.5 \times 10^{12}$ $\mathrm{m}^{2}$. Only 28 freshwater lakes in the world have surface areas greater than $5000 \mathrm{~km}^{2}$, the 
28 lakes have a total surface area of $1.18 \times 10^{12} \mathrm{~m}^{2}$. The organic carbon burial rate in these large lakes is estimated to be 5 $\mathrm{gC} / \mathrm{m}^{2} / \mathrm{yr}$ (Shiklomanov 1993). Current trends indicate eutrophication in Lake Victoria, it is expected that accumulation rate of organic carbon should be equal or higher than $5 \mathrm{gC} / \mathrm{m}^{2} / \mathrm{yr}$. Indeed, the mean accumulation rates of organic carbon and nitrogen in Magu Bay range from 6.92 to $57.25 \mathrm{gC} / \mathrm{m}^{2} / \mathrm{yr}$ and 0.51 to $4.37 \mathrm{gN} / \mathrm{m}^{2} / \mathrm{yr}$, respectively, (Table 3 ) and fall within the reported global range. Lake Ontario, which was experiencing eutrophication before 1980 , has accumulation rates of organic carbon that range from 40 to $160 \mathrm{gC} / \mathrm{m}^{2} / \mathrm{yr}$ whereas that of nitrogen is about $3 \mathrm{gN} / \mathrm{m}^{2} / \mathrm{yr}$ (Schelske and Hodell 1991, Hodell and Schelske 1998). Thus, some of the accumulation rate values in Magu Bay fall within the range of reported accumulation rates in lakes that are experiencing eutrophication.

\section{ACKNOWLEDGEMENT}

This study was supported by funds from Lake Victoria Environmental Management Project. The reviewers are thanked for their comments.

\section{REFERENCES}

Altabet MA, and Francois R 1994 The use of nitrogen isotopic ratio for reconstruction of past changes in surface ocean nutrient utilization. In: Zahn R, Kaminski M, Labeyrie LD, and Pedersen TF (eds) Carbon Cycling in Glacial Ocean: Constraints on the Oceans Role in Global Change. Springer-Verlag, Berlin. p. 281-306

Aravena R, Warner B, MacDonald, G L, and Hanf K, 1992 Carbon isotope compositions of lake sediments in relation to lake productivity and radiocarbon dating. Quaternary Res. 37: 333-345

Canfield D 1994 Factors influencing organic carbon preservation in marine sediments. Chem. Geol. 114: 315329

Deines ET 1980 The isotopic composition of reduced organic carbon. In: Fritz, P., Fontes, J. Ch. (Eds.) Handbook of Environmental Isotope Geochemistry, Vol. 1A. Elsevier, New York, p. 329-406

del Giorgio PA, and France RL 1996 Ecosystem-specific patterns in the relationship between zooplakton and POM or microplankton $\mathrm{d}^{13} \mathrm{C}$. Limnol. Oceanogr. 41: 359-365

Fry B and Sherr EB $1984 \quad \mathrm{~d}^{13} \mathrm{C}$ measurements as indicators of carbon flow in marine and freshwater ecosystems. Contributions in Mar. Sci. 27: 13-47

Hecky RE, Bootsma HA, Mugidde RM and Bugenyi FWB 1996 Phosphorus pumps, nitrogen sinks, and silicon drains: Plumbing nutrients in the African Great Lakes. In: Johnson I.C. and Odada E.O. (eds) The Limnology, Climatology and Paleontology of the East African Lakes. Gordon and Breach Publishers, Amsterdam. p. 205-234

Hodell DA., and Schelske CL 1998 Producition, sedimentation, and isotopic composition of organic matter in Lake Ontario. Limnol. Oceanogr. 43: 200-214

Johanson TC, Scholz CA, Talbot MR, Kelts K, Ricketts RD, Ngobi G, Beuning K, Ssemanda I. and McGill JW 1996 Late Pleistocene desiccation of Lake Victoria and rapid evolution of Cichlid fishes. Science 273: 10911093

Kendall R.L. 1969 An ecological history of the Lake Victoria basin. Ecol. Monogr. 39: 121-176

LaZerte BD 1983 Stable carbon isotope ratios: Implications for the source of sediment carbon and for phytoplankton carbon assimilation in Lake Memphremagog, Quebec. Can. J. Fish. Aquat. Sci. 40: 16581666 
LaZerte BD and Szalados E 1982 Stable isotope ratio of submerged freshwater macrophytes. Limnol. Oceanogr. 27: 413-418

Lipiatou E. Hecky RE, Eisenreich SJ, Lockhart L, Muir D and Wilkinson P 1996 Recent ecosystem changes in Lake Victoria reflected in sedimentary natural and anthropogenic organic compounds. In: Johnson, I.C. and Odada, E.O. (eds) The Limnology, Climatology and Paleontology of the East African Lakes. Gordon and Breach Publishers, Amsterdam. p. 523-541

Machiwa JF, Muzuka ANN, Dubi AM, Ndaro SGM, and Lugomela C 2003Sedimentation studies at the Simiyu River Mouth (Magu Bay, Speke Gulf) Lake Victoria, Tanzania. Lake Victoria Environmental management Project, Dar es salaam. 97p

Meyers PA 1994 Preservation of elemental and isotopic source identification of sedimentary organic matter. Chem. Geol. 114: 289-302

Meyers PA and Ishiwatari R 1993 Lacustrine organic geochemistry-an overview of

indicators of organic matter sources and diagenesis in lake sediments. Org. Geochem. 20: 867 900

Mitchell MJ, Mills EL, Idrisi N and Michener R 1996 Stable isotopes of nitrogen and carbon in an aquatic food web recently invaded by Dreissena polymorpha (Pallas). Can. J. Fish. Aquat. Sci. 53: 14451450

Montoya JP 1994 Nitrogen isotope fractionationin the modern ocean. Implications for the sedimentary record. In: Zahan R, Kaminski M, Labeyrie LD, and Pedersen TF (eds) Carbon Cycling in the Glacial Ocean: Constraints on the Oceans Role in Global Change. Springer, Heldeiberg, p. 259-279
Muzuka ANN 1999a Isotopic compositions of tropical East African flora and their potential as source indicators of organic matter in coastal marine sediments. J. Afr. Earth Sci. 28: 757-766

Muzuka ANN 1999b Stable isotope compositions of sedimentary organic matter off Zanzibar Town. Tanz. J. Sci. 25: 55-70

Muzuka ANN 2001 Sources and diagenetic alteration of organic matter in coastal waters in vicinity of Dar es salaam, Tanzania. Tanz. J. Sci. 27: 39-55

Nakatsuka T, Handa N, Wada E, and Wong SC 1992 The dynamic changes of stable isotopic ratios of carbon and nitrogen in suspended and sedimented particulate organic matter during a phytoplankton bloom. $J$. Mar. Res. 50: 267-296

Pedersen TF, Shimmield GB, and Price NB 1992 Lack of enhanced preservation of organic matter in sediments under the oxygen minimum on the Oman Margin. Geochim. Cosmochim. Acta 5: 545-551

Saggerson, EP 1962 The geology of East Africa. In: Russel, EW (ed). The Natural Resources of East Africa. Hawkins Ltd (in association with the East African Literature Bureau), Nairobi.

Schelske CL and Hodell DA 1991 Recent changes in producitivity and climate of Lake Ontario detected by isotopic analysis of sediments. Limnol. Oceanogr. 36: 961-975

Scholz CA, Rosendahl BR, Versfelt JW and Rach, N. 1990 Results of high -resolution eco-sounding of Lake Victoria. J. Afr. Earth Sci. 11: 2532

Shiklomanov IA 1993 World fresh water resources. In: Glick, P. H ( ed) Water in Crisis. Oxford, Oxford University Press, p. 13-24

Stager JC, Cumming B and Meeker L 1997 A high-resolution $11,400 \mathrm{Yr}$ diatom 
Muzuka et al. - Recent trends in accumulation rate ...

record from Lake Victoria East Africa. Quaternary Res. 47: 81-89

Talbot MR and Livingstone DA 1989 Hydrogen index and carbon isotopes of lacustrine organic matter as lake level indicators. Palaeogeogr. Palaeoclimat. Palaeoecol. 70: 121137

Talbot MR and Laerdal T 2000 The late Pleistocene-Holocene paleoclimatology of
Lake Victoria, East Africa, baed upon elemental and isotopic analyses of sedimentary organic matter. J. Paleoclimat. 23: 141-164 Tenzer GE, Meyers PA and Knoop P 1997 Sources and distribution of organic and carbonate carbon in surface sediments of Pyramid Lake, Nevada. J. Sedimentary Res. 67: 884-890

Tyler CB 1995 Discontinuance of SMOW and PDB. Nature 376: 285 